\title{
REMARKS ON THIRTY-THREE CASES OF SUBDURAL EFFUSION IN INFANCY
}

\author{
BY \\ E. HERZBERGER, Y. ROTEM and J. BRAHAM \\ From the Departments of Neurosurgery, Paediatrics and Neurology, Tel-Hashomer Government Hospital, \\ Tel-Aviv, Israel
}

(RECEIVED FOR PUBLICATION SEPTEMBER 20, 1955)

Following the pioneer work of Ingraham and Matson (1954), the diagnostic possibility of subdural effusion in infancy has excited the interest of paediatricians and neurosurgeons. Guthkelch (1953) remarks that the condition may be regarded as one of the most frequent neurosurgical disorders in infancy, a striking observation when it is considered that up to 10 years ago the diagnosis was rarely made. The absence of a clear history of trauma in many cases, together with the discovery that effusions may follow meningitis, has led many paediatricians to perform subdural taps in a wide range of clinical conditions. Although otherwise unsuspected effusions may be revealed in this way one may be left with an uneasy feeling that the condition is being over-diagnosed, the more so as recognition of the condition carries with it in many cases a firm recommendation to craniotomy.

The purpose of this paper is to present our personal experience of 33 cases treated in the TelHashomer Hospital between 1953 and 1955, and our views regarding various aspects of the problem.

The babies were of an age varying from 1 day to 24 months and in the main were from new immigrant families living in poor conditions. Eighteen were admitted from other institutions with an established diagnosis of subdural effusion.

\section{Aetiology}

In 15 cases there was an antecedent purulent meningitis; the causative organisms were Haemophilus influenzae, pneumococci or meningococci. In three cases a reasonably certain history of birth injury was obtained, and in one a history of a fall. One case was of Torula histolytica encephalitis.

In 13 cases no certain history of trauma could be obtained. It must be emphasized that cooperation with the parents was in many instances not satisfactory and in the kind of homes from which the children came there was ample opportunity for unrecognized trauma.
The pathogenesis of the effusion has already been adequately discussed (Guthkelch, 1953). It should be added that the role of the tap itself is not entirely unsuspect, and it is not always possible to deny that needling may indeed be the cause of local effusion, particularly where it is repeated when initially unproductive. That this is at any rate not always the case was demonstrated in 32 cases of the present series where the first tap did, in fact, reveal fluid. Biochemical examinations of the fluid confirmed the naked-eye impression that it was not identical with cerebrospinal fluid; protein values of the order of 180 to $3,400 \mathrm{mg}$. \% were consistently obtained, whereas in the C.S.F. the average lay between 20 and $180 \mathrm{mg}$. \%.

\section{Pathology}

Opportunities for observation of meningeal and cerebral changes were provided by burr holes (22 cases) and post-mortem examination (seven cases). In three of the latter, burr holes had been made previously, and it was possible to confirm the conclusion that they permitted a reliable impression to be obtained of the state of the underlying structures.

In this way clear evidence of brain damage (excluding simple reversible compression) was seen in 16 out of 22 operated cases. The changes included (a) atrophy, microgyria, scarring-varying in degree from moderate to most severe; $(b)$ oedema, greyish-red discoloration, purulent cortical softening, milky opacity of the pia and pial congestion-these latter occurring chiefly in post-meningitic patients.

Of the seven cases examined at necropsy, one (Case 3) was a baby dying on the day of birth with a large right-sided subdural haematoma (undiagnosed). One died following purulent meningitis and was found to have a thalamic abscess. In four infants the effusion developed during the course of an illness characterized otherwise by gastroenteritis, malnutrition, bronchopneumonia and a 
poor or moribund state on admission. The earliest of these (Case 2), undiagnosed before death, showed cerebral oedema as well as the effusion, and in the others the examination disclosed a very small shrunken firm brain, thrombosis of the superior longitudinal and other dural sinus and cortical venous thrombosis. Subdural membranes were present and a fluid-containing space of $2.5 \mathrm{~cm}$. in average width separated the dura from the brain. Similar changes were seen in Case 25, with the difference that section of the brain here showed many cystic cavities containing white gelatinous material. Histological examination of this white material disclosed Torula histolytica. Figs. 1 and 2 show the high degree of atrophy of the brain seen in Case 22.

A surprising find in this series, and one which we consider of importance in relation to the general management of these patients, was the inconstant relationship of the degree of brain damage on the one hand to the presence and extent of membrane on the other. Variations in this association could be fitted into four groups as follows:-

Group I: No membranes, no macroscopic brain damage.

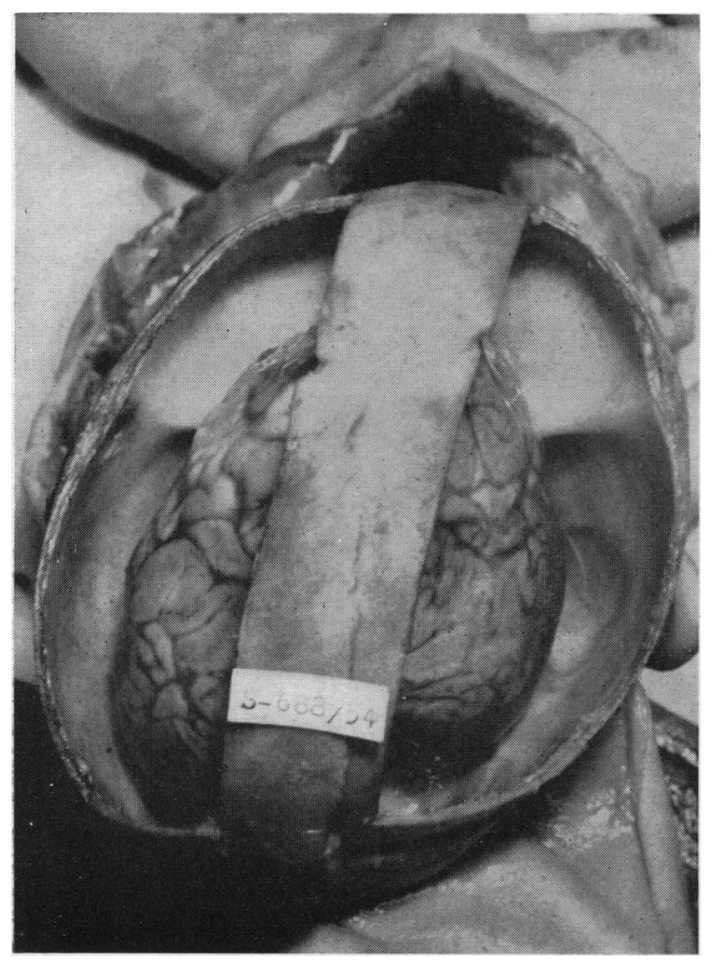

Fig. 1.-Extreme atrophy of the brain in Case 22.
Group II: Thin, ill-defined membranes, no macroscopic brain damage.

Group III: No membranes, but macroscopic brain damage.

Group IV. Well-defined membranes with macroscopic brain damage.

The prognostic and therapeutic implications of these observations are discussed below.

\section{Clinical Features}

The majority of the patients fell into two welldefined clinical groups.

The Post-meningitic Group. This comprised 15 cases. The usual indication for the subdural tap was failure of adequate clinical improvement in spite of appropriate antibiotic therapy, with or without additional neurological complications.

Case 12. An 11-month-old child with Haemophilus influenzae meningitis remained febrile after one week's treatment. Right-sided convulsions appeared, followed by a complete right hemiplegia. A subdural tap disclosed a unilateral, left-sided collection of xanthochromatic fluid containing $1,300 \mathrm{mg}$. \% protein and 160 leucocytes. Persistence of the fluid after four taps for

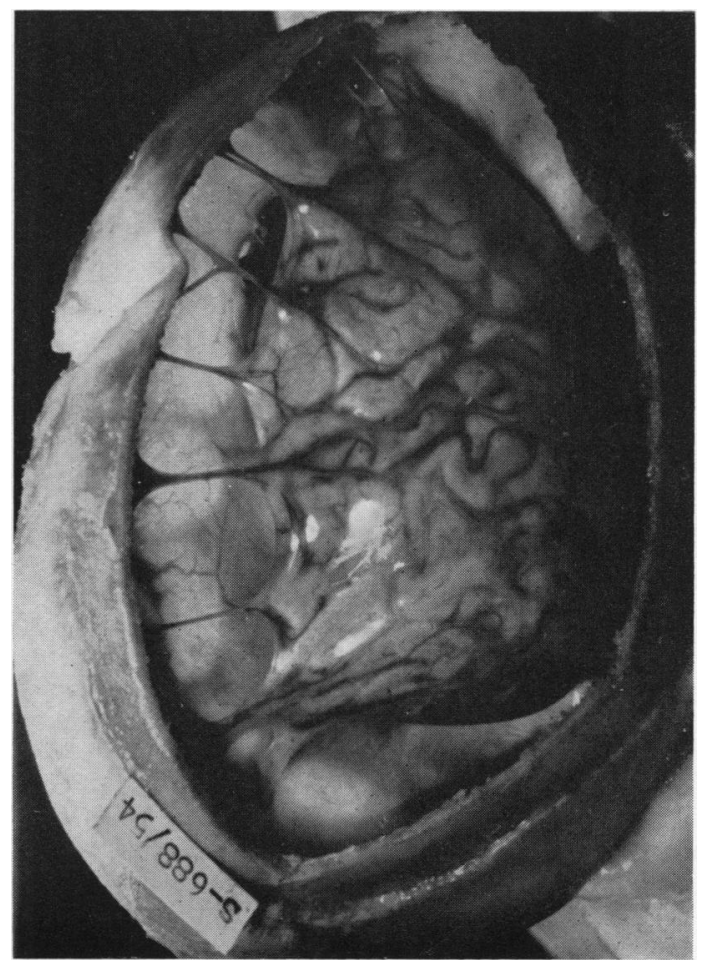

Fig. 2.-Thrombosed cortico-dural vessels are seen crossing the greatly enlarged subdural space (Case 22 ). 
two weeks led to the performance of a left temporal burr hole which revealed a thick, friable, greenish-brown membrane applied to the pia arachnoid. At the subsequent craniotomy the membrane was stripped off fairly easily except for one small part where it was firmly adherent to the cortex. The child made a gradual, but full recovery.

The Non-meningitic Group. The non-meningitic group can be divided into 'cerebral' and systemic types.

A 'Cerebral' TyPe. The four infants in this group presented with convulsions, vomiting, some evidence of mental retardation and bulging fontanelle, in various combinations. In three there was a certain or probable history of birth injury; one was diagnosed later as torulosis.

'SYSTEMIC' GrouP. In these 12 infants the clinical features were such as are appropriate to a diagnosis of malnutrition, gastro-enteritis or bronchopneumonia, either alone or in combination. Their general condition was very poor and they failed to respond to a régime of hydration, adequate feeding and the treatment of infection. The first case in this group came to necropsy with the effusion undiagnosed, thus providing a stimulus to the performance of exploratory subdural taps in the infants with a similar clinical background and unsatisfactory course.

As the number of cases in this group indicates, the exploration was rewarding to a surprising degree, and this constitutes a unique and special feature of the series presented here. One can hardly disprove that trauma had played no part in the aetiology; on the other hand where trauma was reasonably certain the clinical picture was quite different. Again, the discovery on so many occasions of a collection of fluid at the initial subdural tap might seem largely to allay any natural suspicions that the needling caused the effusion. The reversal of the general condition in most instances after treatment of the effusion is further evidence of probably more than circumstantial significance.

Case 2. An infant, aged 5 months, was admitted with one week's history of diarrhoea and vomiting before admission, and during the last few days swelling of the legs. On admission there was fever, non-pitting oedema, rickets, malnutrition and enlargement of spleen and liver. The blood protein level was $2.5 \mathrm{mg}$. \% with $1: 1$ albumin-globulin ratio; $\mathrm{Hb} 10 \cdot 6 \mathrm{~g}$. \%, leucocytes 6,200 per c.mm. The administration of fluids (11 infusions), vitamins and antibiotics did not succeed in bringing about any improvement. Bronchopneumonia appeared and the general condition deteriorated and the baby died six weeks after admission.

At necropsy, in addition to the expected changes in the lungs, large bilateral subdural effusions and moderate cerebral oedema were found. There was no membrane formation.

Case 33. A 3-month-old infant was admitted to another hospital because of gastro-enteritis of one week's duration. There was severe malnutrition and dehydration with anaemia ( $\mathrm{Hb} 8.4 \mathrm{~g}$. \%, leucocytes 4,200 per c.mm., red blood cells 2.7 millions per c.mm.). Antibiotics and the administration of fluids produced no response. Subdural taps showed bilateral accumulations of fluid containing $255 \mathrm{mg}$. \% protein and 3 cells per c.mm. Lumbar puncture on the same day yielded C.S.F. containing $50 \mathrm{mg}$. \% protein and 27 cells per c.mm., and 5-10 ml. of fluid were removed from each side. The tap was repeated once, and the infant then referred to this hospital. Clinical improvement was already noted at this stage. One further tap was performed which was dry on the left; from the right side $3 \mathrm{ml}$. of fluid were aspirated.

One week later bitemporal burr holes were made and nothing abnormal found. The child continued to make a rapid recovery.

Two other cases, not fitting into the above major groups, are of some interest. One was a 4-month-old infant (Case 27) admitted because of hydrocephalus. This was of the communicating type, and during the course of investigations a thick membrane was discovered over the left hemisphere. Craniotomy and removal of the membrane did not influence the hydrocephalus in any way. The other (Case 5), an infant aged 9 months, suffered from intermittent and unexplained fever for several weeks. Because of the history of a fall some days preceding the onset of fever and some degree of bulging of the fontanelle, bilateral taps were performed and effusions found over both hemispheres.

\section{Treatment}

In seven of the cases (five post-meningitic and two 'gastro-enteritic') the effusions responded to evacuation by repeated taps, some $8-15 \mathrm{ml}$. of fluid being removed on each occasion. As it happened, the fourth tap in each of these patients was dry and no further action was taken in view of the rapid clinical recovery.

Failure of the effusion to respond to this simple measure led to the performance of burr holes in 22 patients. Fluid was evacuated and the brain and its coverings inspected. Membrane was seen in half of the infants submitted to this procedure. In two cases the membrane (unilateral) was thick, greenish and adherent to the arachnoid and was removed at subsequent craniotomy (the postHaemophilus meningitis and the hydrocephalus cases respectively). In the remaining nine cases the membrane was thin, whitish and applied only to the inner surface of the dura, but not adherent to the arachnoid. Craniotomy, although contemplated, 
was not carried out in the first place because of the very poor general condition of these infants. However, when it was seen that this minor procedure was followed by a considerable change for the better, the more formidable intervention of craniotomy was deliberately withheld in subsequent cases where this kind of poorly-developed membrane was found. In others visible brain damage seemed to preclude the necessity for craniotomy for removal of membrane which, not being applied to the brain, could presumably not be causing such damage.

\section{Results}

Repeated taps, from two to four in number, sufficed to bring about apparent cure in five meningitis cases and in two enteritis-malnutrition cases. All six of the 22 submitted to burr holes, in whom no brain damage was seen (Group I and II above), did very well. Of the Group III cases (brain damage without membrane), seven improved but were not considered to do as well as those without brain damage. One case in this group with universal spasticity of the limbs failed to respond in any way. Group IV (well-marked membrane, brain damage) with eight cases contained the most seriously ill children. Three died, three recovered to a degree comparable to that of the previous group and two were treated by craniotomy, with results as described. As seen from Table 1, the results correlate well with the degree of brain damage, the presence or absence of membrane being of less importance.

\section{Discussion and Conclusions}

From the clinical point of view our material seems to be of special interest because of the inclusion of a high proportion of cases-about one-third of the total-in which the clinical course would not normally be considered to be related to the presence of subdural effusion. The post-mortem findings in a missed case result in increased awareness of this possibility in infants with non-cerebral syndromes and an unsatisfactory clinical course. Other workers in this area are alert in seeking and detecting these cases (Levine, 1953) as is also shown above by the number of instances in which the infants were referred from other institutions with the diagnosis already established. It may be that the effusion in these cases can be related to the readiness of infants in a subtropical climate to develop dehydration, with consequent reduction in brain volume and thus the creation of an actual instead of a potential subdural space. Altered capillary permeability and local congestion due to marantic phlebo-thrombosis perhaps then constitute further pre-conditions for seepage into such a space. In 16 of these patients, brain damage was in fact seen, varying in severity from moderate oedema to pathogenetic bilateral atrophy with multiple sinus thrombosis. Another possibility, gastro-enteritis, may be regarded as yet another infection, liable to complication by intracranial venous thrombosis (Symonds, 1952). One may speculate that treatment by antibiotics and attention to fluid and electrolytic imbalance preserve life long enough to allow the further development of these effusions; this chain of circumstances could perhaps also account for their increased incidence in recent years.

From the neurosurgical viewpoint our approach has been conservative, and only two craniotomies were performed in the whole series. The decision not to perform this operation routinely on the discovery of membrane represents a departure from Ingraham and Matson's recommendations. We were satisfied at the time these children were treated that clinical recovery was either rapid and complete, or compatible with what could be expected in the light of existing brain damage. Final justification clearly must depend on a prolonged follow-up, with estimates of physical and intellectual development during the school years, the presence or absence of fits and perhaps repeated electroencephalographic studies.

TABLE 1

CLINICAL RESULTS IN RELATION TO PATHOLOGICAL FINDINGS

\begin{tabular}{|c|c|c|c|c|c|c|c|}
\hline & & & & $\begin{array}{l}\text { Group I:* No Membrane } \\
\text { and No Brain Damage }\end{array}$ & $\begin{array}{l}\text { Group II: Membrane, } \\
\text { but No Brain Damage }\end{array}$ & $\begin{array}{c}\text { Group III : No Membrane, } \\
\text { but Brain Damage }\end{array}$ & $\begin{array}{l}\text { Group IV: Membrane, but } \\
\text { Brain Damage }\end{array}$ \\
\hline $\begin{array}{l}\text { Excellent } \\
\text { Good } \\
\text { Moderate } \\
\text { Poor } \\
\text { Death }\end{array}$ & $\begin{array}{l}\cdots \\
\cdots \\
\cdots \\
\cdots\end{array}$ & $\begin{array}{l}\ldots \\
\ldots \\
\cdots \\
\cdots\end{array}$ & $\begin{array}{l}\ldots \\
\cdots \\
\cdots \\
\cdots \\
\cdots\end{array}$ & $\frac{9}{-}$ & $\begin{array}{l}3 \\
1 \\
- \\
-\end{array}$ & $\begin{array}{l}-5 \\
3 \\
1 \\
2\end{array}$ & $\begin{array}{l}- \\
2 \\
1 \\
1 \\
5\end{array}$ \\
\hline
\end{tabular}

Excellent $=$ full recovery within two weeks. Good $=$ slow but continuous improvement until discharge and subsequently. Moderate $=$ general clinical improvement but with delay in development according to age. Poor $=$ mental and neurological defects with no improvement.

* Group I includes cases treated by taps without exploration of the subdural space. 


\begin{tabular}{|c|c|c|c|c|c|c|}
\hline $\begin{array}{l}\text { Case } \\
\text { No. }\end{array}$ & $\begin{array}{l}\text { Age and } \\
\text { Sex }\end{array}$ & $\begin{array}{l}\text { Duration of } \\
\text { Illness on } \\
\text { Admission }\end{array}$ & $\begin{array}{c}\text { Predominant Clinical } \\
\text { Syndrome }\end{array}$ & Aetiology & C.S.F. Findings & Subdural Fluid Findin \\
\hline 1 & $2 \frac{1}{2}$ months & & Purulent meningitis & Negative culture & 1,900 cells, $157 \mathrm{mg} . \%$ & 164 cells, $720 \mathrm{mg}$. \\
\hline 2 & 5 months & 10 days & $\begin{array}{l}\text { Gastro-enteritis, malnutrition, } \\
\text { fever, bronchopneumonia }\end{array}$ & Negative culture & $\begin{array}{l}4 \text { cells, } 35 \mathrm{mg} . \% \\
\text { protein }\end{array}$ & Not diagnosed \\
\hline 3 & 1 day & 1 day & $\begin{array}{l}\text { Convulsions, coma, bulging } \\
\text { fontanelle }\end{array}$ & Birth injury & Blood-stained & Not diagnosed \\
\hline 4 & 9 months & 6 weeks & Gastro-enteritis, malnutrition & Negative culture & $\begin{array}{l}3 \text { cells, } 40 \mathrm{mg} . \% \\
\text { protein }\end{array}$ & $\begin{array}{l}20 \text { cells, } 350 \mathrm{mg} \text {. } \\
\text { protein }\end{array}$ \\
\hline 5 & 9 months & 7 weeks & $\begin{array}{l}\text { Febrile state only, bulging } \\
\text { fontanelle }\end{array}$ & $\begin{array}{l}\text { Trauma of head } \\
\text { at } 7 \text { months }\end{array}$ & $\begin{array}{l}2 \text { cells, } 25 \mathrm{mg} . \% \\
\text { protein }\end{array}$ & $\begin{array}{l}\text { No cells, } 400 \mathrm{mg} \text {. } \\
\text { protein }\end{array}$ \\
\hline 6 & 15 days & 1 week & Convulsions, bulging fontanelle & Birth injury & 870 erythrocytes, 180 & $\begin{array}{l}\text { No cells, } 1,000 \mathrm{mg} \text {. } \\
\text { protein }\end{array}$ \\
\hline 7 & $12 \underset{M}{\text { months }}$ & 4-5 months & $\begin{array}{l}\text { Mental deficiency, spasticity, } \\
\text { bulging fontanelle }\end{array}$ & Birth injury & $\begin{array}{l}40 \text { cells, } 25 \mathrm{mg} . \% \\
\text { protein }\end{array}$ & $\begin{array}{l}\text { No cells, } 200 \mathrm{mg} . \% \\
\text { protein }\end{array}$ \\
\hline 8 & 4 months & 8 weeks & Purulent state after meningitis & $\begin{array}{l}\text { Haemophilus } \\
\text { influenzae }\end{array}$ & $\begin{array}{l}20 \text { cells, } 40 \mathrm{mg} . \% \\
\text { protein }\end{array}$ & $\begin{array}{l}\text { No cells, } 180 \mathrm{mg} \text {. } \\
\text { protein }\end{array}$ \\
\hline 9 & $5 \frac{1}{2}$ months & 3 months & Gastro-enteritis, malnutrition & Negative culture & $\begin{array}{l}4 \text { cells, } 35 \mathrm{mg} . \% \\
\text { protein }\end{array}$ & $\begin{array}{l}10 \text { cells, } 416 \mathrm{mg} \text {. } \\
\text { protein }\end{array}$ \\
\hline 10 & 3 months & $3 \frac{1}{2}$ weeks & Purulent meningitis & Pneumococci & 860 cells (polynuclears), & 120 cells (polynucle \\
\hline 11 & 5 months & 3 months & Gastro-enteritis, malnutrition & Negative culture & $\begin{array}{l}5 \text { cells, } 15 \text { mg. } \% \\
\text { protein }\end{array}$ & $\begin{array}{l}260 \text { cells, } 675 \mathrm{mg} \text {. } \\
\text { protein }\end{array}$ \\
\hline 12 & $9 \frac{1}{2}$ months & 1 day & $\begin{array}{l}\text { Purulent meningitis, later right } \\
\text { hemiplegia }\end{array}$ & $\begin{array}{l}\text { Haemophilus } \\
\text { influenzae }\end{array}$ & $\begin{array}{l}2,500 \text { cells (polynuclear) } \\
180 \mathrm{mg} . \% \text { protein }\end{array}$ & $\begin{array}{l}160 \text { cells, } 1,350 \mathrm{mg} . \\
\text { protein }\end{array}$ \\
\hline 13 & $2 \frac{1}{2}$ months $_{M}$ & 2 days & Purulent meningitis & Pneumococci & $\begin{array}{l}1,400 \text { cells (polynuclear), } \\
165 \mathrm{mg} . \% \text { protein }\end{array}$ & $\begin{array}{l}60 \text { cells, } 1,500 \mathrm{mg} . \\
\text { protein }\end{array}$ \\
\hline 14 & 4 months & 3 days & Purulent meningitis & Meningococci & $\begin{array}{l}4,000 \text { cells (polynuclear), } \\
182 \mathrm{mg} . \% \text { protein }\end{array}$ & $\begin{array}{l}132 \text { cells, } 720 \mathrm{mg} \text {. } \\
\text { protein }\end{array}$ \\
\hline 15 & 6 months & 2 weeks & State after purulent meningitis & Meningococci & $\begin{array}{l}45 \text { cells, } 30 \mathrm{mg} . \% \\
\text { protein }\end{array}$ & $\begin{array}{l}900 \text { cells, } 1,500 \mathrm{mg} \text {. } \\
\text { protein }\end{array}$ \\
\hline 16 & 12 months & 1 day & Purulent meningitis & Pneumococci & $\begin{array}{l}5,000 \text { cells (polynuclear), } \\
205 \mathrm{mg} . \% \text { protein }\end{array}$ & $\begin{array}{l}250 \text { cells, } 890 \mathrm{mg} \\
\text { protein }\end{array}$ \\
\hline 17 & 9 months & 3 weeks & State after purulent meningitis & Negative culture & $\begin{array}{l}5 \text { cells, } 15 \mathrm{mg} . \% \\
\text { protein }\end{array}$ & $\begin{array}{l}120 \text { cells, } 450 \mathrm{mg} \\
\text { protein }\end{array}$ \\
\hline 18 & 4 months & 4 weeks & State after purulent meningitis & Meningococci & $\begin{array}{l}66 \text { cells, } 25 \mathrm{mg} . \% \\
\text { protein }\end{array}$ & 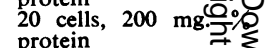 \\
\hline 19 & 5 months & 1 day & Purulent meningitis & Pneumococci & 1,100 cells (polynuclear), & 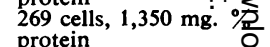 \\
\hline 20 & 13 months & 1 day & Purulent meningitis & Pneumococci & 2,300 cells, $200 \mathrm{mg} . \%$ & 68 cells, $750 \mathrm{mg}$. \\
\hline 21 & $\begin{array}{l}8 \text { months } \\
? ?\end{array}$ & 4 weeks & Gastro-enteritis, malnutrition & Negative culture & $\begin{array}{l}5 \text { cells, } 20 \mathrm{mg} . \% \\
\text { protein }\end{array}$ & $\begin{array}{l}\text { No cells, } 278 \mathrm{mg} \text {. } \\
\text { protein }\end{array}$ \\
\hline 22 & 7 months & 3 months & $\begin{array}{l}\text { Gastro-enteritis, malnutrition, } \\
\text { convulsions, spasticity, mental }\end{array}$ & Negative culture & $\begin{array}{l}8 \text { cells, } 25 \mathrm{mg} . \% \\
\text { protein }\end{array}$ & $\begin{array}{l}613 \text { cells, } 3,400 \mathrm{mg} . \\
\text { protein }\end{array}$ \\
\hline 23 & $? ?$ & 4 weeks & $\begin{array}{l}\text { Gastro-enteritis, malnutrition, } \\
\text { convulsions, fever }\end{array}$ & Negative culture & $\begin{array}{l}4 \text { cells, } 20 \mathrm{mg} . \% \\
\text { protein }\end{array}$ & $\begin{array}{l}5 \text { cells, } 180 \mathrm{mg} . \% \\
\text { protein }\end{array}$ \\
\hline 24 & 5 months & 5 weeks & Gastro-enteritis, malnutrition & Negative culture & $\begin{array}{l}3 \text { cells, } 20 \mathrm{mg} . \% \\
\text { protein }\end{array}$ & $\begin{array}{l}\text { No cells, } 180 \mathrm{mg} \text {. \%ి } \\
\text { protein }\end{array}$ \\
\hline 25 & 6 months & 6 weeks & $\begin{array}{l}\text { Convulsions, vomiting, bulging } \\
\text { fontanelle }\end{array}$ & $\begin{array}{l}\text { Torula } \\
\text { histolytica }\end{array}$ & $\begin{array}{l}2 \text { cells, } 15 \mathrm{mg} . \% \\
\text { protein }\end{array}$ & $\begin{array}{l}25 \text { cells, } 425 \mathrm{mg} . \% \\
\text { protein }\end{array}$ \\
\hline 26 & 6 months & 4 months & Gastro-enteritis, malnutrition & Negative culture & 5 cells, $28 \mathrm{mg} . \%$ & 12 cells, $240 \mathrm{mg}$. 욕 \\
\hline 27 & 7 months & 4 months & $\begin{array}{l}\text { Large communicating hydro- } \\
\text { cephalus }\end{array}$ & $\begin{array}{l}\text { Unknown birth } \\
\text { injury? Degen- } \\
\text { erative? }\end{array}$ & $\begin{array}{l}\text { No cells, } 15 \mathrm{mg} . \% \\
\text { protein }\end{array}$ & $\begin{array}{l}\text { No cells, } 1,200 \mathrm{mg} \cdot \frac{\mathrm{x}}{8} \\
\text { protein }\end{array}$ \\
\hline 28 & 10 months & 6 weeks & $\begin{array}{l}\text { Gastro-enteritis, malnutrition, } \\
\text { bronchopneumonia }\end{array}$ & Negative culture & $\begin{array}{l}\text { No cells, } 20 \mathrm{mg} . \% \\
\text { protein }\end{array}$ & $\begin{array}{l}52 \text { cells, } 1,800 \mathrm{mg} . \\
\text { protein }\end{array}$ \\
\hline 29 & 5 months & 2 weeks & State after purulent meningitis & Meningococci & $\begin{array}{l}33 \text { cells, } 40 \mathrm{mg} . \% \\
\text { protein }\end{array}$ & $\begin{array}{l}56 \text { cells, } 480 \mathrm{mg} \text {. } \\
\text { protein }\end{array}$ \\
\hline 30 & $4 \underset{F}{\text { months }}$ & 1 day & Purulent meningitis & Pneumococci & $\begin{array}{l}8,600 \text { cells (polynuclear), } \\
210 \mathrm{mg} \text {. } \% \text { protein }\end{array}$ & $\begin{array}{l}8,250 \text { cells, } 780 \mathrm{mg} \text {. } \\
\text { protein }\end{array}$ \\
\hline 31 & 5 months & 8 days & $\begin{array}{l}\text { Gastro-enteritis, malnutrition, } \\
\text { bronchopneumonia }\end{array}$ & Negative culture & $\begin{array}{l}\text { No cells, } 60 \mathrm{mg} . \% \\
\text { protein }\end{array}$ & $\begin{array}{l}7 \text { cells, } 300 \mathrm{mg} \text {. } \\
\text { protein }\end{array}$ \\
\hline 32 & 3 months & 3 months & State after purulent meningitis & Negative culture & $\begin{array}{l}80 \text { cells, } 180 \mathrm{mg} . \% \\
\text { protein }\end{array}$ & 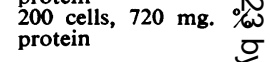 \\
\hline 33 & 3 months & 4 weeks & Gastro-enteritis, malnutrition & Bact. coli $\mathrm{O} 111$ & $\begin{array}{l}27 \text { cells, } 50 \mathrm{mg} . \% \\
\text { protein }\end{array}$ & $\begin{array}{l}3 \text { cells, } 255 \mathrm{mg} . \\
\text { protein }\end{array}$ \\
\hline
\end{tabular}

* Left craniotomy. 


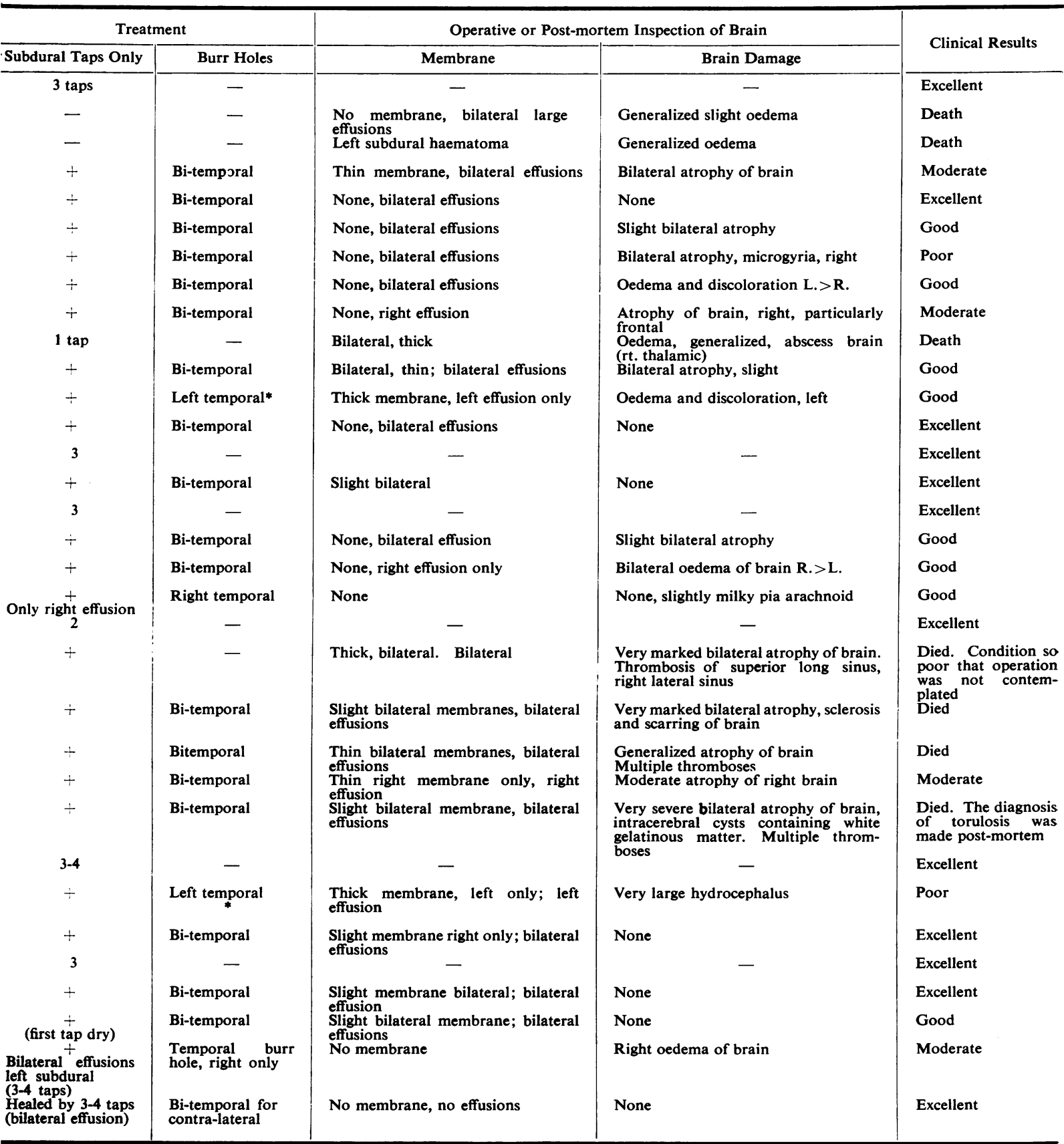




\section{Summary}

A series of 33 cases of subdural effusion in infancy is presented. In four only was there a reasonable certainty of a traumatic aetiology; 15 followed purulent meningitis and in 12 the effusion appeared in the course of a general illness with gastroenteritis, malnutrition and bronchopneumonia.

Neurosurgical intervention was limited to burr holes in 22 cases; craniotomy for removal of the membrane was performed on two occasions only.

The immediate results of such conservative management were considered to justify withholding major surgery, though final opinion must wait upon a long follow-up.

It is a pleasure to acknowledge the cooperation of the paediatricians of the ' $A$ ' and ' $B$ ' Paediatric Departments of the Tel-Hashomer Hospital.

We are also much indebted to the physicians in charge of the Paediatric Departments of the Assaf Harofe (Sarafand), Zahalon (Jaffa), Rambam (Haifa), Schweitzer (Tiberias) and Hadassah (Tel-Aviv) Hospitals who referred many of the cases.

\section{REFERENCES}

Guthkelch, A. N. (1953). Brit. med. J., 1, 233.

Ingraham, F. D. and Matson, D. D. (1954). Neurosurgery of Infancy and Childhood, $456 \mathrm{pp}$. Springfield, Illinois.

Levine, S. (1953). Personal communication.

Symonds, C. P. (1952). Ann. roy. Coll. Surg. Engl., 10, 347. Quoted by Guthkelch. 